\title{
Potential Applications of Some Indigenous Bacteria Isolated from Polluted Areas in the Treatment of Brewery Effluents
}

\author{
Temesgen Oljira $\left(\mathbb{D},{ }^{1,2}\right.$ Diriba Muleta $\mathbb{D}^{\mathbb{D}},{ }^{3}$ and Mulissa Jida $\mathbb{D}^{1,4}$ \\ ${ }^{1}$ Microbiology and Microbial Biotechnology Graduate Program, Department of Biology, Wollega University, Nekemte, Ethiopia \\ ${ }^{2}$ Industrial Biotechnology Unit, Department of Biotechnology, Wolkite University, Wolkite, Ethiopia \\ ${ }^{3}$ Environmental Biotechnology Unit, Biotechnology Institute, Addis Ababa University, Addis Ababa, Ethiopia \\ ${ }^{4}$ Environmental Biotechnology Directorate, Ethiopian Biotechnology Institute, Addis Ababa, Ethiopia
}

Correspondence should be addressed to Temesgen Oljira; galataaoljirraa@gmail.com

Received 26 August 2017; Accepted 26 October 2017; Published 11 February 2018

Academic Editor: Yau Hung Chen

Copyright (C) 2018 Temesgen Oljira et al. This is an open access article distributed under the Creative Commons Attribution License, which permits unrestricted use, distribution, and reproduction in any medium, provided the original work is properly cited.

\begin{abstract}
Biological wastewater treatment is economically feasible and ecofriendly. This study was aimed at isolating bacteria from brewery wastes and evaluating their bioremediation potential as individual isolate and/or their consortium in reducing the pollutants of brewery effluents. A total of 40 bacterial isolates were recovered and of these the three best isolates were selected. The selected bacteria were identified to genus level by using morphological and biochemical characteristics. Accordingly, the isolates were identified as Aeromonas sp., Pseudomonas sp., and Bacillus sp. After 12 days of incubation, the removal efficiency of these three isolates and their combinations for biological oxygen demand and chemical oxygen demand varied from $73.55 \%$ to $94.85 \%$ and $76.78 \%$ to $93.25 \%$, respectively. Total nitrogen and phosphorus removal was within the range of $54.43 \%$ to $77.21 \%$ and $41.80 \%$ to $78.18 \%$, respectively. Total suspended solid, total solid, and total dissolved solids removal ranged from $66.74 \%$ to $90.3 \%, 54.69 \%$ to $88.5 \%$, and $53.02 \%$ to $88.2 \%$, respectively. The $\mathrm{pH}$ and electrical conductivity values ranged from 6.81 to 8.65 and $3.31 \mathrm{mS} / \mathrm{cm}$ to $3.67 \mathrm{mS} / \mathrm{cm}$, respectively. The treated effluent increased Beta vulgaris seeds germination from $80 \%$ to $100 \%$, with mean germination time of 3.1 to 5.2 days and seedlings length of $2.3 \mathrm{~cm}$ to $6.3 \mathrm{~cm}$. Therefore, the development of this finding into a large scale offers an attractive technology for brewery waste treatment.
\end{abstract}

\section{Introduction}

Industries are major source of pollution in all environments. Brewery plants have been known to cause pollution by discharging effluent into receiving stream, ground water, and soil in Ethiopia [1]. Environmental concern that can be associated with brewery wastewater include biochemical oxygen demand (BOD), chemical oxygen demand (COD), total suspended solid (TSS), $\mathrm{pH}$, nutrients (nitrogen and phosphorus) concentration, and temperature [2]. Brewery industry wastewater contains organic waste with pollution levels depending on the beer production process and capacity of water consumption during the process [3].

Untreated brewery effluents typically contain suspended solids in the range $10-60 \mathrm{mg} / \mathrm{l}, \mathrm{BOD}$ in the range $1,000-$ $1,500 \mathrm{mg} / \mathrm{l}$, COD in the range $1800-3000 \mathrm{mg} / \mathrm{l}$, and nitrogen in range $30-100 \mathrm{mg} / \mathrm{l}$ [4]. Effluent $\mathrm{pH}$ can fluctuate from 3 to
12 depending on the use of acid and alkaline cleaning agents as well as the temperatures average becomes about $30^{\circ} \mathrm{C}$ [5].

Currently, in Ethiopia, there are ten breweries. It is reported that the majority of brewery industries in Ethiopia discharge their wastewaters into nearby water bodies and open land with little or no prior treatment [1]. The effluent from rural breweries is used for irrigation purposes. However, the breweries effluent in urban areas is directly discharged into rivers without any prior treatment.

One of the wastewater treatment systems which is economically feasible and environmentally sound is a biological treatment using microorganisms [6]. This system uses microbial activity to oxidize organic compounds with the aid of molecular $\mathrm{O}_{2}$ into $\mathrm{CO}_{2}$, water, and a new cell [7]. In recent years, there has been increasing interest to the use of waste stabilization ponds to treat the brewery wastewater [8]. Another highly recommended method for the effective 
treatment of brewery effluent is the use of constructed wetlands [9].

Brewery and other industries are blooming in Ethiopia; as a result, pollution of the environment is increasing. Thus, isolation and identification of effective microorganisms are a novel approach to minimize the current environmental problems. The objective of this study was to assess the potential of bacterial isolates in the treatment of brewery effluents and also to confirm removal of pollutants by conducting germination test on seeds of beet root (Beta vulgaris).

\section{Materials and Methods}

2.1. Description of the Study Area. The study was conducted at Bedele Brewery Microbiology and Wastewater Treatment Laboratory. The industry was founded in 1993, which is located at $483 \mathrm{~km}$ south west of Addis Ababa in Buno Bedele zone, Oromia Regional State. Bedele town is located at a longitude and latitude of $8^{\circ} 27^{\prime} \mathrm{N} 36^{\circ} 21^{\prime} \mathrm{E}$ and with an elevation between 2,012-2,162 meters (6,601-7,093 ft) above sea level.

2.2. Sampling and Sample Collection. Brewery waste samples were collected from three sources. These were brewery effluent, sludge of waste, and contaminated soil with brewery effluents. One liter of effluent, two $\mathrm{kg}$ of sludge, and soil samples were collected aseptically using sterile glass bottles. Samples of soil, sludge, and effluent were labeled and analyzed separately. The samples were collected three times $(3 \mathrm{x})$ from three sources by the interval of 15 days to get different bacterial isolates. The samples were stored at $4^{\circ} \mathrm{C}$ until further analysis.

\subsection{Isolation and Purification of Waste Degrading Bacteria.} The samples were serially diluted in physiological saline $(0.9 \% \mathrm{NaCl} \mathrm{w} / \mathrm{v}$ solution $)$ and $0.1 \mathrm{ml}$ of aliquots from appropriate dilution was spread plated on nutrient agar (NA) (Hi-Media, Mumbai, India). All the plates were incubated aerobically at $30^{\circ} \mathrm{C}$ for $48-72 \mathrm{hrs}$. The plates were observed for bacterial growth. Morphologically different colonies were selected from plates with countable colonies and transferred to nutrient broth (NB) (Hi-media, Mumbai, India) and checked for purity by repeated streaking on NA plates. The pure isolates were designated based on their sources of isolation, from soil (SO), effluent (EF), and sludge (SL) followed by number codes. The pure cultures were preserved on NA slant at $4^{\circ} \mathrm{C}$ and $50 \%$ glycerol at $-10^{\circ} \mathrm{C}$ in duplicate for further study. The day to day experimentation was carried out with cultures maintained on plates and slants. The isolates were periodically checked for purity.

2.4. Preparation of Inoculum for the Experiment. Inoculum was prepared following the method outlined by Krishnaswamy et al. [10]. Sterile nutrient broth $(10 \mathrm{ml})$ was prepared and a loopful of 24-hour-old selected colonies of bacterial isolates on NA were inoculated separately and incubated for $48 \mathrm{hrs}$ at room temperature. The bacterial cells were recovered by centrifuging at $3500 \mathrm{rpm}$ for $15 \mathrm{~min}$ and washed. The resulting supernatant was discarded and pellet was resuspended in $0.9 \% \mathrm{NaCl}$ solution. The optical density (OD) was adjusted to $\mathrm{OD}_{0.5}$ by diluting cell suspension with $0.9 \%$ $\mathrm{NaCl}$ at a wavelength of $660 \mathrm{~nm}$ and measured using spectrophotometer (Cadas 200; Germany).

After the $\mathrm{OD}$ of the suspension was adjusted to $\mathrm{OD}_{0.5}$; $0.1 \mathrm{ml}$ was spread plated on nutrient agar to estimate number of viable cells per $\mathrm{ml}$ of suspension. The number of bacterial cells used for inoculation is presented in Table 1. Furthermore, after the OD of each isolate was adjusted, $50 \mathrm{ml}$ of cell suspension was added to $250 \mathrm{ml}$ of sterilized brewery wastewater and $300 \mathrm{ml}$ of total volume was prepared.

2.5. Design of the Study and Pollutant Removal Experiment. Experiment on pollutant removal of bacterial isolates was conducted at laboratory scale batch culture in bottle under shaking at $150 \mathrm{rpm}$. The brewery wastes were sterilized by autoclaving separately. The bacterial isolates were inoculated aseptically to that of sterilized wastes in different bottles in three duplicates. The bottles were incubated at room temperature on a shaker maintained at $150 \mathrm{rpm}$. Bottles with only brewery wastes (without addition of microbes) were used as a control. In this study, three different potential bacterial isolates were selected. Selection of potential bacterial isolates was based on pollutant removal efficiency after 12th day of incubation. These three isolates EF-01(A), SL-10(C), and SO-25(D) showed the best ability to degrade the brewery wastewater and were selected to constitute their combinations (Table 1).

The three isolates that showed the best performance in removal efficiency of the brewery wastewater pollution profile were revived from their stock cultures and subcultured. A loopful of each individual isolate of $24 \mathrm{hrs}$ old on NA was aseptically inoculated into sterile nutrient broth medium $(10 \mathrm{ml})$ in test tubes. The inoculated test tubes were incubated for $48 \mathrm{hrs}$ at $30^{\circ} \mathrm{C}$. The bacterial broth cultures were adjusted at $\mathrm{OD}_{0.5}$. Thereafter, well-mixed cell suspension was added to sterilized brewery wastewater. The inoculated bottles containing wastewater were incubated.

In this study, $\mathrm{pH}, \mathrm{EC}, \mathrm{BOD}, \mathrm{COD}, \mathrm{TN}, \mathrm{TP}, \mathrm{TSS}, \mathrm{TS}$, and TDS were selected to measure pollutants removal activity of bacterial isolates. The parameters were measured before and after inoculation of potential bacterial isolates. The measurement was carried on $0,3 \mathrm{rd}, 6 \mathrm{th}, 9 \mathrm{th}$, and 12 th days for all parameters. After the measurement of the selected brewery wastewater parameters, pollutants reduction capabilities of bacterial isolates (singly or in combination) were evaluated. Percentage of pollutants removal was compared against the control (without bacterial inoculation).

2.6. Compatibility Test of the Selected Bacterial Species. Before combination, compatibility test was performed among the three selected potential bacteria. Each of the three selected isolates was grown at room temperature and subsequently tested by the cross-streaking method at $30^{\circ} \mathrm{C}$ and at $37^{\circ} \mathrm{C}$ [11]. The isolates were inoculated as a $1.5 \mathrm{~cm}$ wide streak (instead of $1 \mathrm{~cm}$ ) diametrically across duplicate nutrient agar plates. The plates were incubated overnight at either room temperature or $37^{\circ} \mathrm{C}$. The selected strains were streaked singly at right angles to the original inoculum by using a wire loop (three strains per plate). The plates were incubated at $30^{\circ} \mathrm{C}$ and $37^{\circ} \mathrm{C}$ 
TABLE 1: Treatment design and number of bacteria cells (CFU) estimated per $\mathrm{ml}$ of suspension.

\begin{tabular}{|c|c|c|c|}
\hline Treatment & Isolate code & Designation & $\begin{array}{c}\text { Mean colony forming unit } \\
\text { per } \mathrm{ml} \text { of suspension } \times \\
10^{6} \mathrm{CFU} / \mathrm{ml}\end{array}$ \\
\hline $\mathrm{T} 1$ & EF-01(A) & A & $2.75 \pm 10$ \\
\hline $\mathrm{T} 2$ & SL-10(C) & $\mathrm{C}$ & $2.85 \pm 17$ \\
\hline T3 & SL-25(D) & $\mathrm{D}$ & $2.77 \pm 14$ \\
\hline $\mathrm{T} 4$ & Comb 1 & $C+D$ & $2.76 \pm 24$ \\
\hline T5 & Comb 2 & $A+C+D$ & $2.76 \pm 26$ \\
\hline T6 & Control & Not inoculated & - \\
\hline
\end{tabular}

T: treatment and Comb: combination.

overnight, and inhibition was recorded where the indicator strains crossed the original inoculum.

\subsection{Characterization and Identification of Selected Bacterial} Isolates. Pure colonies of selected potential bacterial isolates were characterized using morphological and biochemical tests. The colony characteristics such as size, shape, color, margin, and elevation were recorded with their biochemical tests.

2.7.1. Morphological and Biochemical Characterization of Bacterial Isolates. The morphological characteristics used for identification were colony size, surface (smooth, rough, granular, and papillate), color (colorless, pink, black, red, and bluish-green), margin (entire, wavy, lobate, and filiform), elevation (flat, raised, low convex, and dome shaped), and their shape such as bacilli/rod, cocci/spherical, and spiral under a microscope. Moreover, cell arrangement (single, chain, pair, diploid, tetrad, and cluster), gram staining, and spore forming test were considered for morphological characterization of the selected isolates. The biochemical tests performed in this study were $\mathrm{KOH}$, catalase, oxidase, and Oxidation Fermentation $(\mathrm{O} / \mathrm{F})$ tests.

2.8. Brewery Effluent Analysis. Pollutant concentration of each treatment sample was analyzed for selected pollutant parameters following standard methods [12].

2.8.1. Electrical Conductivity and $p H$. Electrical conductivity (EC) was measured with a conductivity meter (Oyster conductivity meter). The $\mathrm{pH}$ of the samples was measured with a portable $\mathrm{pH}$ meter (Model HI9024, HANNA Instrument) [12].

2.8.2. Biochemical Oxygen Demand (BOD). BOD was determined by respirometer method by using BOD Trak $\mathrm{II}^{\mathrm{TM}}$ instrument (HACH Company, Loveland, CO, USA) [13]. Diluted sample was transferred into BOD bottle and the instrument was sealed to prevent external atmospheric pressure changes in the test bottle at $20^{\circ} \mathrm{C}$ for five days. The result was shown graphically in milligrams per liter $(\mathrm{mg} / \mathrm{l})$ on a liquid crystal display.

2.8.3. Chemical Oxygen Demand (COD). The chemical oxygen demand was measured by closed reflux method using strong chemical oxidant [14]. The oxidant used for this study was a mixture of potassium dichromate $\left(\mathrm{KCr}_{2} \mathrm{O}_{7}\right)$. Finally, COD was determined by a method of colorimetric determination using $\mathrm{HACH}$ DR3900 spectrophotometer $(\mathrm{HACH}$ Company, Loveland, CO, USA). Results were displayed in $\mathrm{mg} / \mathrm{l} \mathrm{COD}$ by spectrophotometer. If the sample actual COD was higher than the range, the sample was diluted but the real results were multiplied by dilution multiple.

2.8.4. Total Nitrogen (TN). Total nitrogen was determined by using persulfate digestion method by oxidation of all nitrogenous compounds to nitrate [13]. This was done by alkaline oxidation at $105^{\circ} \mathrm{C}$ to convert organic and inorganic nitrogen to nitrate. Total nitrogen was determined by analyzing the nitrate in the digester. It was measured by using DR3900 spectrophotometer (HACH Company, Loveland, CO, USA) in $\mathrm{mg} / \mathrm{lN}$.

2.8.5. Total Phosphorus (TP). To measure TP vanadomolybdophosphoric acid colorimetric method was used [13]. The intensity of the yellow color was proportional to phosphate concentration. The result was read by DR3900 spectrophotometer (HACH Company, Loveland, CO, USA) in $\mathrm{mg} / 1$ $\mathrm{PO}_{4}{ }^{3-}$. Conversion of total $\mathrm{PO}_{4}{ }^{-3}$ to total $\mathrm{P}$ was calculated by using molecular weight of $\mathrm{P}$ in $\mathrm{PO}_{4}{ }^{-3}$. Therefore, Total $\left(\mathrm{PO}_{4}{ }^{-3}\right)\left(\mathrm{mg} / \mathrm{l}\right.$ as $\left.\mathrm{PO}_{4}{ }^{-3}\right) \times 0.3263=$ Total $\mathrm{P} \mathrm{mg} / \mathrm{l}[15]$.

2.8.6. Total Solids (TS), Total Suspended Solids (TSS), and Total Dissolved Solids (TDS). Total solids, total suspended solids, and total dissolved solids were determined by gravimetric method at temperature of $103-105^{\circ} \mathrm{C}$ [13]. For total solids, clean crucibles were weighed using an analytical balance (Kern PFP balance IBECOR, Germany). The crucible dish was then heated for 1 hour in an oven at $103^{\circ} \mathrm{C}$, allowed to cool, and then reweighed. This was recorded as the initial weight, B. A $50 \mathrm{ml}$ of each of the samples was introduced into the crucibles and evaporated using water bath. After evaporation for $24 \mathrm{hrs}$, the crucibles and the residues in them were dried in the oven for $2 \mathrm{hrs}$ at $103^{\circ} \mathrm{C}$ and then cooled in a desiccator and the weight taken as final weight, $A$. The total solid was estimated using the following formula:

$$
\mathrm{TS}(\mathrm{mg} / \mathrm{L})=\frac{(A-B) \times 1000}{\text { Volume }(\mathrm{mL}) \text { of sample }} .
$$


Total suspended solid (TSS) was analyzed by filtering of the sample through the preweighed filter paper. Filter paper was then dried at $103-105^{\circ} \mathrm{C}$. TSS was determined by using the following formula [13]:

$$
\operatorname{TSS}(\mathrm{mg} / \mathrm{L})=\frac{(A-B) \times 1000}{\text { Volume }(\mathrm{mL}) \text { of sample }},
$$

where $A$ was the weight of filter plus dried residue and $B$ was the weight of filter paper.

Total dissolved solid (TDS) was analyzed by a well-mixed sample filtered through a standard glass fiber filter, and the filtrate was evaporated to dryness in a preweighed dish $(B)$ $\mathrm{mg}$ and dried to constant weight at $180 \pm 2^{\circ} \mathrm{C}$ for one hour in oven and then cooled in a desiccator and weighed $(A) \mathrm{mg}$. The increase in dish weight represents the total dissolved solids. TDS was determined by using the following formula [14]:

$$
\operatorname{TDS}(\mathrm{mg} / \mathrm{L})=\frac{(A-B) \times 1000}{\text { Volume }(\mathrm{mL}) \text { of sample }},
$$

where $A$ is weight of dried residue $+\operatorname{dish}, \mathrm{mg}$, and $B$ is weight of dish, mg.

2.9. Germination Test. Pollutants removal was confirmed by germination test of wastewater treated with individual and combination of the bacterial isolates. For this test, seeds of beet root (Beta vulgaris) were bought from Buno Bedele Seed Enterprise. Seeds of beet were sterilized with $70 \% \mathrm{v} / \mathrm{v}$ ethanol for five minutes, followed by repeated washings using sterilized double distilled water. Sterile plastic Petri dishes were used with double layer Whatman filter paper no. 1 in two replicates from each treatment. Ten healthy treated seeds of uniform size per Petri dishes were used. Seeds were spread at equal distance in each Petri dish lined with round filter paper. Then each labeled Petri dish with seeds was irrigated with $5 \mathrm{ml}$ of different treatments of wastewater and then incubated at $25 \pm 2^{\circ} \mathrm{C}[16]$.

Different parameters like germination percentage, mean germination time (MGT), and seedling length were recorded at different time intervals of plant growth. First recording was done after $12 \mathrm{hrs}$ of incubation and subsequent recordings were done at a day interval till the 6th day of incubation. The Petri dishes were rearranged at random on every one day to ensure no systematic effects due to positioning within the incubator.

2.9.1. Germination (\%). Germination in each experimental set was recorded and total germination was calculated and expressed in percentage [17]:

$$
\text { Germination } \%=\frac{\sum n}{N}
$$

whereas $n$ is number of seeds geminated and $N$ is total number of seeds sowed.

2.9.2. Mean Germination Time (MGT). The mean germination time was calculated using the daily counts for each lot [17].

$$
\mathrm{MGT}=\frac{\sum n \cdot D}{\sum n},
$$

where $n$ is number of seeds germinated in the $i$ th time (not the accumulated number, but the number correspondent to the $i$ th observation), $D$ is days from the beginning of the germination test, and $\sum n$ is total of germinated seeds.

2.9.3. Seedling Length $(\mathrm{cm})$. The shoot length was measured from the base of the primary leaf to the base of the hypocotyl and the mean shoot length was expressed in centimeter. Root length was measured from the tip of the primary root to the base of hypocotyl and mean root length was expressed in centimeter. By adding the root length and shoot length, seedling length was calculated and expressed in centimeter.

2.10. Data Analysis. Statistical analysis was performed using SPSS program (SPSS; Version 20.0). The data were analyzed through one-way analysis of variance (ANOVA) at 95\% confidence level to compare the performance efficiency of each individual and combination treatments. Means separation was done following Duncan's test.

\section{Results and Discussion}

A total of 40 different bacterial isolates with diverse morphological characteristics were retrieved from brewery effluent, sludge, and soil contaminated with brewery wastewater. Out of 40 isolates, the best three bacteria were selected as potential organisms for waste treatment technology.

3.1. Morphological and Biochemical Tests of Selected Potential Bacteria. Based on the cultural characteristics, morphological tests, and biochemical tests (Table 2), these selected bacterial isolates were assigned to three genera, namely, Aeromonas sp. (EF-01), Pseudomonas sp. (SL-10), and Bacillus sp. (SO-25).

3.2. Brewery Effluent Analysis before and after Treatment. The appearance of brewery wastes before and after treatment is shown in Figure 1. The results of the study demonstrated that after 12 days of incubation, measured parameters for pollutants decreased and their removal efficiency (\%) was increased.

The $\mathrm{pH}$ and EC values were slightly increased. The pollutant parameter values of before and after treatment are indicated in Table 3.

Pollutant removal efficiency (\%) of these three individual isolates and their combination is presented in Table 4. From individual isolates, Bacillus sp. had high pollutant removal efficiency for all parameters, except for TN. Similarly from combination treatments, the highest removal efficiency was in combination 2 .

3.2.1. Effect of Inoculation on $p H$ and EC. The results of the study demonstrated that $\mathrm{pH}$ values increased in all the treatments (Figure 2). The $\mathrm{pH}$ values were between 6.81 and 8.56 for all the treatments. The value of the control treatment 


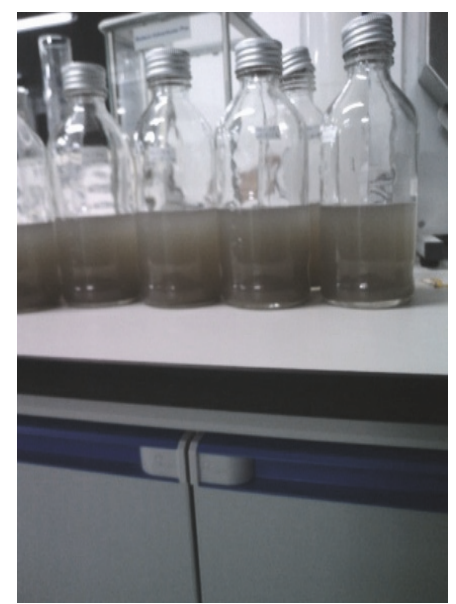

(a)

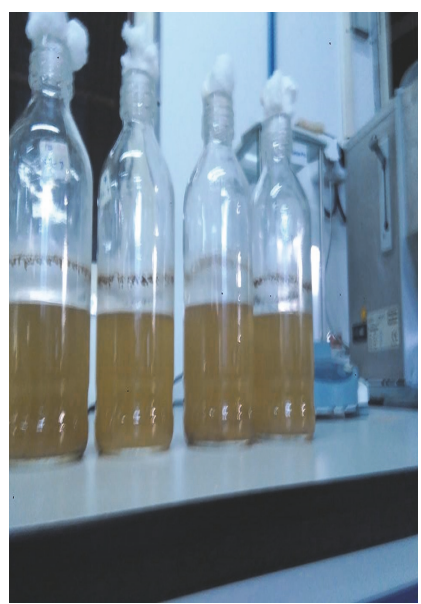

(b)

FIGURE 1: Wastewater samples before (a) and after (b) treatment.

TABLE 2: Morphological and biochemical characteristics of selected bacterial isolates.

\begin{tabular}{lccc}
\hline Test & EF-01 & SL-10 & SO-25 \\
\hline Surface & Smooth & Smooth & Rough \\
Colony shape & Circular & Irregular & Irregular \\
Color & Greenish yellow & white & White \\
Margin & Entire edge & Filamentous & Lobate \\
Elevation & Flat & Convex & Raised \\
Cell shape & Rod & Rod & Rod \\
Gram stain & - & - & + \\
KOH test & + & + & - \\
Endospore & - & - & + \\
Catalase test & + & + & + \\
Oxidase test & + & + & + \\
O/F test & $\mathrm{F}^{+}$ & $\mathrm{O}^{+}$ & -
\end{tabular}

Suggested genus Aeromonas sp. Pseudomonas sp. Bacillus sp.

O: oxidative, F: fermentative, +: positive, - : negative, SL: isolated from sludge, EF: isolated from effluent, and SO: isolated from soil.

was significantly $(p<0.05)$ lower than all the treatments. Of the individual isolates, $\mathrm{pH}$ value of effluent inoculated with Pseudomonas (SL-10) $(\mathrm{pH}=8.22)$ was the lowest $(p<$ $0.05)$ compared to all the treatments. However, the highest $(p<0.05)$ value was measured in effluent inoculated with Aeromonas sp. (EF-01) $(\mathrm{pH}=8.48)$. The $\mathrm{pH}$ values of all combination treatments were significantly higher $(p<0.05)$ than all other individual isolate treatments (Table 3 ).

A study conducted by Choudhary et al. [18] showed that an increase of $\mathrm{pH}$ in treated effluent suggested that there has been activity of microorganisms that degrade organic matter. Similarly, Paramita et al. [19] have stated that degradation of proteins and organic nitrogen into ammonium $\left(\mathrm{NH}_{4}\right)$ raises the $\mathrm{pH}$ and becomes alkaline. The same finding by Anggraeni et al. [20] also showed that consortium of Cronobacter sp. strain, Pseudomonas fluorescens, and Aeromonas sp. of bacteria isolated from soil contaminated with brewery wastewater

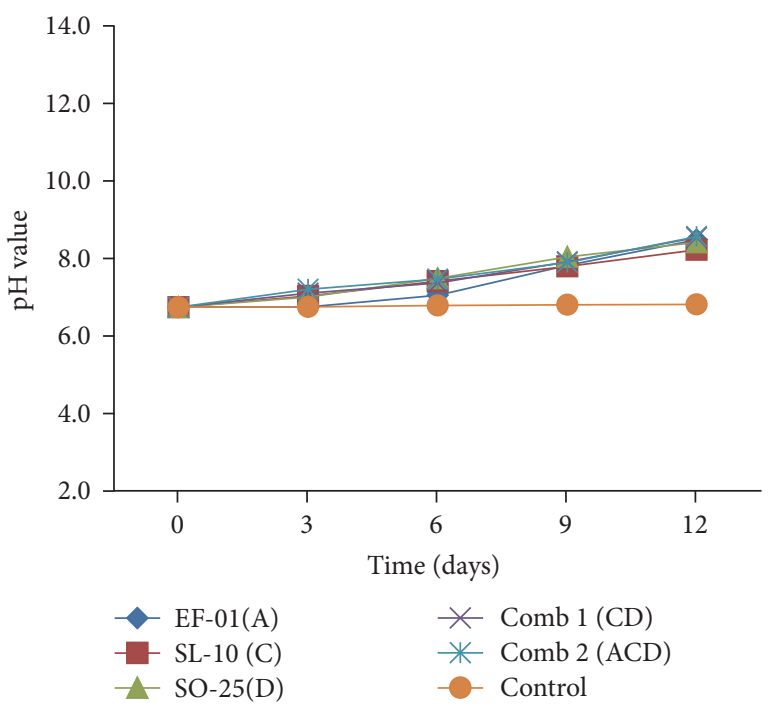

Figure 2: $\mathrm{pH}$ values of individual and combination treatments. A: Aeromonas sp., C: Pseudomona sp., D: Bacillus sp., and Comb: combination.

reduced the pollutants but $\mathrm{pH}$ value was increased by activity of microorganisms. Gaikwad et al. [21] have also reported that Pseudomonas and actinomycetes reduce pollutant parameters of complex wastewater but $\mathrm{pH}$ value was increased.

Similar to $\mathrm{pH}$, the EC values of all the treatments were slightly increased in all the isolates (Figure 3). EC values ranged from 3.31 to $3.67 \mathrm{mS} / \mathrm{cm}$ for all the treatments. Treatment comb 2 had high EC with value of $3.67 \mathrm{mS} / \mathrm{cm}$ with significant $(p<0.05)$ difference compared to all other treatments.

The conductivity of a solution depends on the concentration of all the ions present; the greater their concentrations, the greater the conductivity. The rise in EC values is related to the increment observed in $\mathrm{pH}$ values (i.e., an increase in $\mathrm{OH}^{-} / \mathrm{H}^{+}$ions) that ultimately posed increase in EC values. 


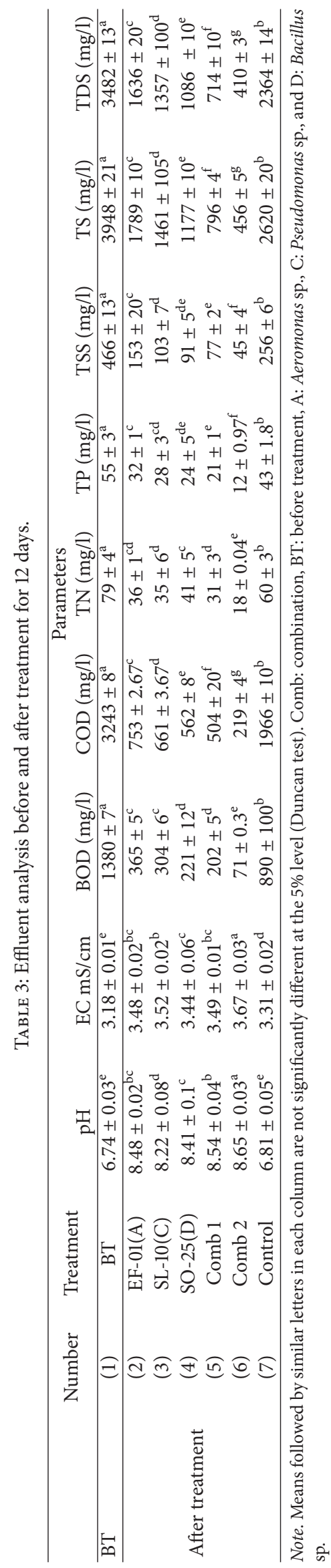


TABLE 4: Pollutant removal efficiency (\%) of three selected isolates and their combination after 12 days of incubation.

\begin{tabular}{|c|c|c|c|c|c|c|c|c|c|}
\hline \multirow{2}{*}{ Treatment } & \multicolumn{9}{|c|}{ Parameters and their removal efficiency (\%) } \\
\hline & $\mathrm{pH}$ & $\mathrm{EC}(\mathrm{mS} / \mathrm{cm})$ & BOD & $\mathrm{COD}$ & $\mathrm{TN}$ & $\mathrm{TP}$ & TSS & TS & TDS \\
\hline EF-01(A) & $8.48^{\mathrm{bc}}$ & $3.48^{\mathrm{bc}}$ & $73.55^{\mathrm{e}}$ & $76.78^{\mathrm{e}}$ & $54.43^{\mathrm{c}}$ & $41.8^{\mathrm{e}}$ & $66.74^{\mathrm{e}}$ & $54.69^{\mathrm{e}}$ & $53.02^{\mathrm{e}}$ \\
\hline SL-10(C) & $8.22^{\mathrm{d}}$ & $3.52^{\mathrm{b}}$ & $77.97^{\mathrm{d}}$ & $79.61^{\mathrm{d}}$ & $56.7^{\mathrm{b}}$ & $49.1^{\mathrm{d}}$ & $77.9^{\mathrm{d}}$ & $63.0^{\mathrm{d}}$ & $61.02^{\mathrm{d}}$ \\
\hline SO-25(D) & $8.41^{\mathrm{c}}$ & $3.44^{\mathrm{c}}$ & $84.0^{\mathrm{c}}$ & $82.67^{\mathrm{c}}$ & $48.1^{\mathrm{d}}$ & $56.36^{\mathrm{c}}$ & $80.5^{\mathrm{c}}$ & $70.18^{\mathrm{c}}$ & $68.81^{\mathrm{c}}$ \\
\hline Comb $1(\mathrm{CD})$ & $8.54^{\mathrm{b}}$ & $3.49^{\mathrm{bc}}$ & $85.36^{\mathrm{b}}$ & $84.50^{\mathrm{b}}$ & $60.76^{\mathrm{b}}$ & $61.8^{\mathrm{b}}$ & $83.5^{\mathrm{b}}$ & $79.84^{\mathrm{b}}$ & $79.50^{\mathrm{b}}$ \\
\hline Comb 2(ACD) & $8.65^{\mathrm{a}}$ & $3.67^{\mathrm{a}}$ & $94.85^{\mathrm{a}}$ & $93.25^{\mathrm{a}}$ & $77.21^{\mathrm{a}}$ & $78.18^{\mathrm{a}}$ & $90.3^{\mathrm{a}}$ & $88.5^{\mathrm{a}}$ & $88.2^{\mathrm{a}}$ \\
\hline Control & $6.81^{\mathrm{e}}$ & $3.31^{\mathrm{d}}$ & $35.52^{\mathrm{f}}$ & $39.38^{\mathrm{f}}$ & $24.05^{\mathrm{e}}$ & $21.8^{\mathrm{f}}$ & $45.1^{\mathrm{f}}$ & $33.64^{\mathrm{f}}$ & $32.12^{f}$ \\
\hline
\end{tabular}

Note. Means followed by similar letters in each column are not significantly different at the $5 \%$ level (Duncan test). Legend: as listed in Table 3.

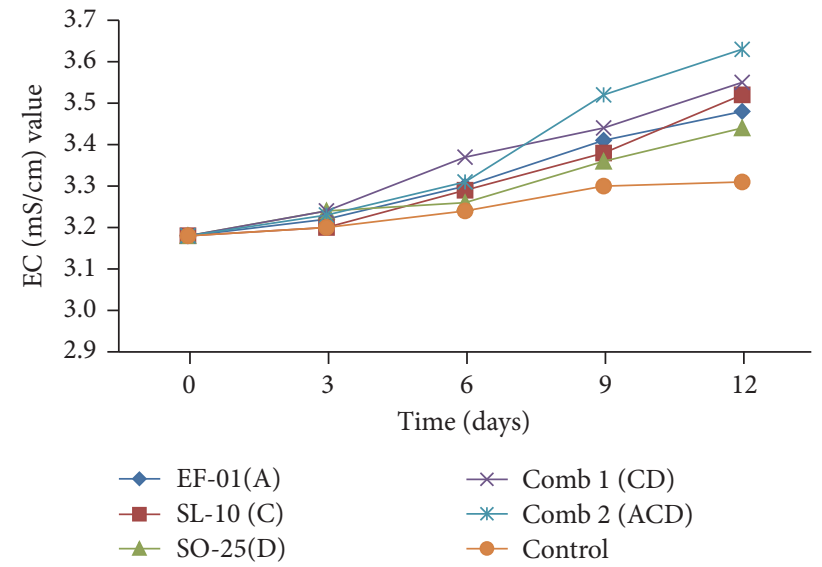

FIGURE 3: EC $(\mathrm{mS} / \mathrm{cm})$ values of individual and combination treatments. A: Aeromonas sp., C: Pseudomona sp., D: Bacillus sp., and Comb: combination.

For an acidic solution, the lower the $\mathrm{pH}$ is, that is, the higher the $\mathrm{H}^{+}$concentration, the greater the conductivity will be. So, strongly acidic or strongly basic solution will have high conductivity [22]. In all treatments, $\mathrm{pH}$ values have met Ethiopian standard limit (6-9) values but none of them met for $\mathrm{EC}\left(1000 \mu \mathrm{s} / \mathrm{cm}\right.$ at $\left.20^{\circ} \mathrm{C}\right)$.

3.2.2. BOD and COD Reduction. The results of the current study showed a decline in the values of BOD and COD in the three individual isolates and their two mixed combinations (Table 3). After 12 days of incubation, all the treatments had BOD and COD values ranging from $71 \mathrm{mg} / \mathrm{l}$ to $365 \mathrm{mg} / \mathrm{l}$ and from $219 \mathrm{mg} / \mathrm{l}$ to $753 \mathrm{mg} / \mathrm{l}$, respectively. The minimum reduction of BOD was caused by Aeromonas sp. (EF-01) but the maximum reduction was recorded from combined treatments (Table 3). Bacillus sp. (SO-25) caused considerable reduction of BOD from $1380 \mathrm{mg} / \mathrm{l}$ to $221 \mathrm{mg} / \mathrm{l}$ and COD from $3243 \mathrm{mg} / \mathrm{l}$ to $562 \mathrm{mg} / \mathrm{l}$ compared to all other bacterial isolates from day 0 to 12 th day, respectively. The maximum $(219 \mathrm{mg} / \mathrm{l})$ reduction of COD was recorded in effluents inoculated with three combined bacterial isolates.

The Ethiopian standard limits for BOD and COD emission of brewery waste are $60 \mathrm{mg} / \mathrm{l}$ and $250 \mathrm{mg} / \mathrm{l}$, respectively. From all the treatments, only samples treated with three combinations (comb 2) met the Ethiopian standard limit for COD values. In the case of BOD, none of them met the Ethiopian standard limit. However, their removal percent/efficiency was acceptable.

Figures 4(a) and 4(b) show the average BOD and COD removal efficiency of each individual isolate. The removal efficiency was between $73.55 \%$ and $94.85 \%$ for BOD and $76.78 \%$ to $93.25 \%$ for COD. From individual isolates, maximum (84\%) BOD removal measured in the treatment inoculated with Bacillus sp. but minimum (73.55\%) in Aeromonas sp. treatment. In case of BOD removal, all the individual isolates and their combination showed statistically significant $(p<0.05)$ differences compared to the control. Likewise, tremendous COD removal was recorded by Bacillus sp. (82.67\%), Pseudomonas sp. (SL-10) (79.61\%), and Aeromonas sp. $(76.78 \%)$ with significant differences $(p<0.05)$ between each individual isolates and the control.

In both $\mathrm{BOD}$ and $\mathrm{COD}$, the maximum removal efficiency was recorded by three mixed combinations with values of $94.85 \%$ and $93.25 \%$, respectively. The findings indicate that the reduction of BOD and COD increases in effluent inoculated with bacterial isolates with the extension of incubation period. Similarly, Metcalf and Eddy [23] have reported that the organic matter contained in the wastewater serves as a substrate for aerobic microbial metabolism which could lead to a decrease in BOD and COD concentration.

According to Hidayah and Shovitri [24], microbes are able to live based on the ability to compete for nutrients with other microbes depending on the types of nutrients present in the medium. Autochthonous microbes can adapt faster to the environment and nutrition in accordance with their origin. Microbes that are able to adapt more quickly can efficiently break down organic materials contained in the waste [25]. Pseudomonas is a common bacterium capable of degrading pollutants [20] although not so efficient in the current study compared to other isolates. High COD reduction in the treatment of brewery effluent by Pseudomonas species has also been reported [26].

Further, according to Mongkolthanaruk and Dharmsthiti [27], mixed bacterial culture comprising Pseudomonas aeruginosa, Bacillus sp., and Acinetobacter calcoaceticus were used in the treatment of lipid-rich wastewater. Similarly, Surti [28] has reported that bacterial strains of Pseudomonas aeruginosa, Bacillus subtilis, Enterobacter aerogenes, and mixed culture of these three bacterial strains are used for COD reduction of wastewater from pharmaceutical industry. 


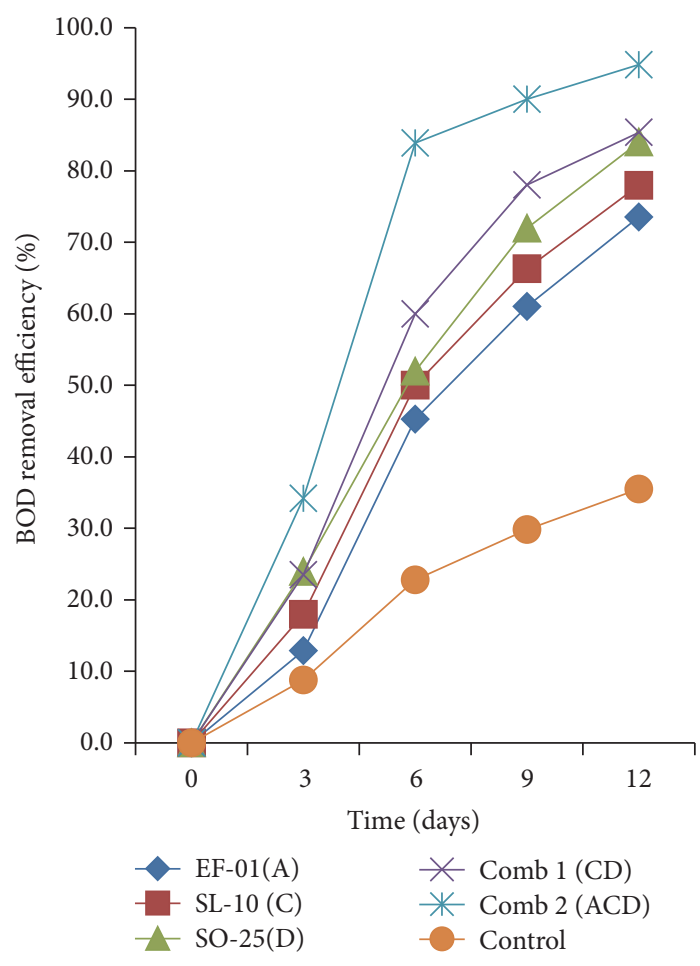

(a)

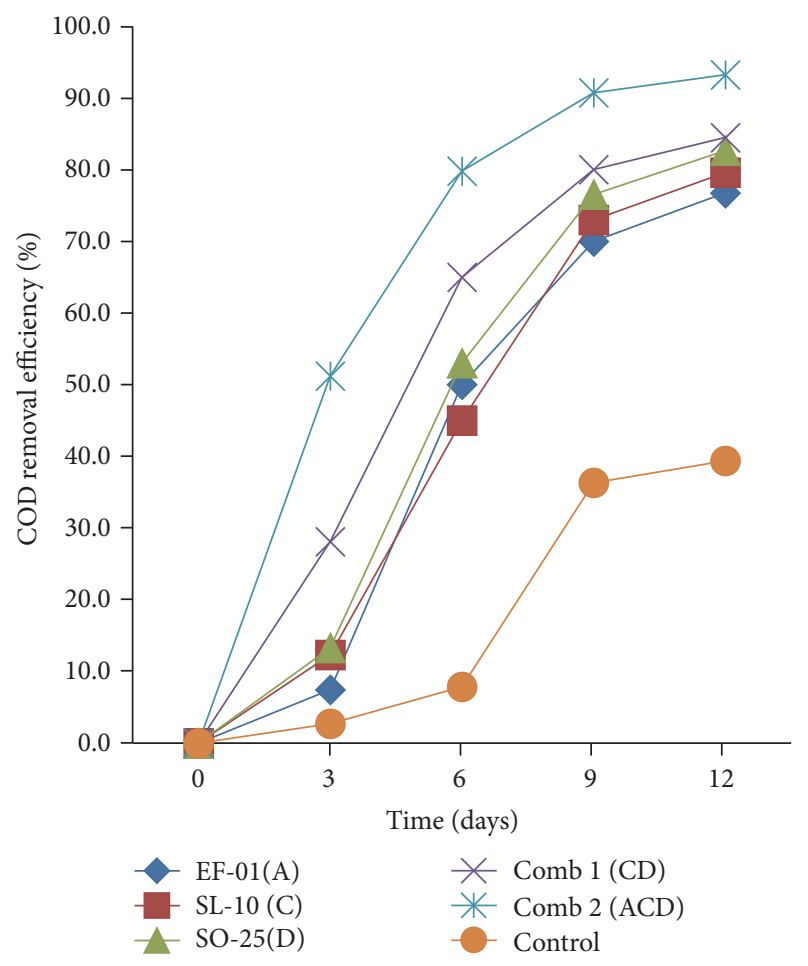

(b)

Figure 4: BOD (a) COD (b) removal efficiency (\%) of individual and combination treatments. A: Aeromonas sp., C: Pseudomona sp., D: Bacillus sp., and Comb: combination.

3.2.3. Total Nitrogen Removal Efficiency. In this study, the results showed that mean TN ranged from $36 \mathrm{mg} / \mathrm{l}$ to $41 \mathrm{mg} / \mathrm{l}$ with $48.1 \%$ to $56.7 \%$ removal efficiency for individual isolates. Similarly, for combination treatment, TN values ranged from $18 \mathrm{mg} / \mathrm{l}$ to $34 \mathrm{mg} / \mathrm{l}$ with removal efficiency of $60.76 \%$ to $77.21 \%$ (Figure 5). Nitrogen removal efficiency of all the isolates and their combination treatments showed significant $(p<0.05)$ difference compared to the control (without bacterial inoculation). TN removal efficiency of the three individual isolates was also significantly $(p<0.05)$ different with each other. Out of the three isolates, Pseudomonas sp. (SL-10) was significantly removed TN (56.7\%) followed by Aeromonas sp. (54.43\%) and Bacillus sp. (48.1\%).

The highest removal efficiency of TN was in the treatment with three combinations of isolates. The combination (consortium) of bacteria showed significant $(p<0.05)$ difference in efficiency of total nitrogen removal from the treated effluents compared to the individual isolates. This might be because of their synergistic effect on pollutant removal.

The Ethiopian standard limit for TN emission of brewery waste is $40 \mathrm{mg} / \mathrm{l}$. Removal of TN for individual isolates is relatively comparable to the national effluent emission standard limit for brewery wastewater for Aeromonas sp. (36 mg/l) and Pseudomonas sp. (SL-10) (35 mg/l). In case of combination treatments both of them met the standards.

Compared to other pollutant removal parameters, TN removal efficiencies of all the isolates were lower than other parameters since most denitrifying heterotrophic bacteria are incomplete denitrifiers, which were only capable of reducing

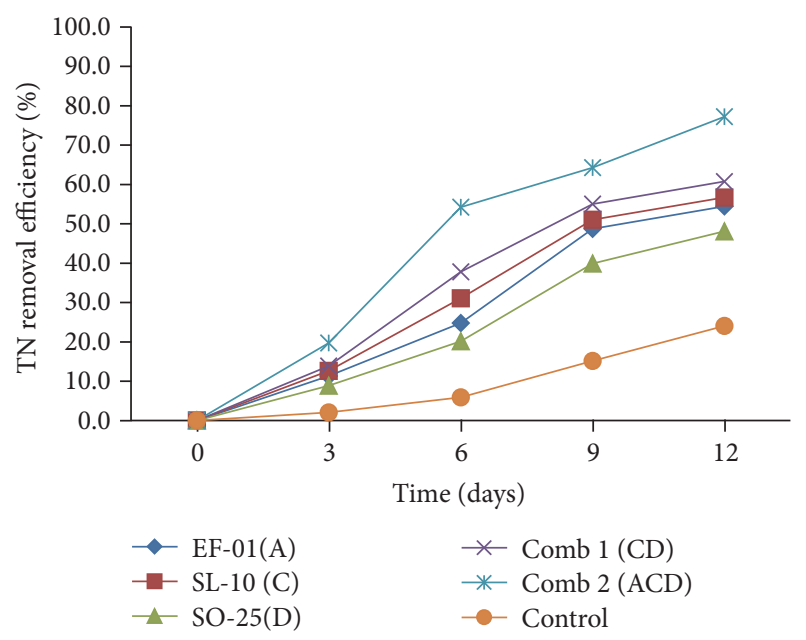

FIGURE 5: TN removal efficiency (\%) of individual and combination treatments. A: Aeromonas sp., C: Pseudomona sp., D: Bacillus sp., and Comb: combination.

nitrates to nitrites with no further reduction of the nitrites produced. This is because incomplete denitrifying bacteria lack key nitrite reductase enzymes which enable complete denitrifiers to reduce nitrites [29]. The true denitrifying bacteria were able to reduce both nitrates as well as nitrites. Pseudomonas sp. is predominated among the true denitrifiers. 


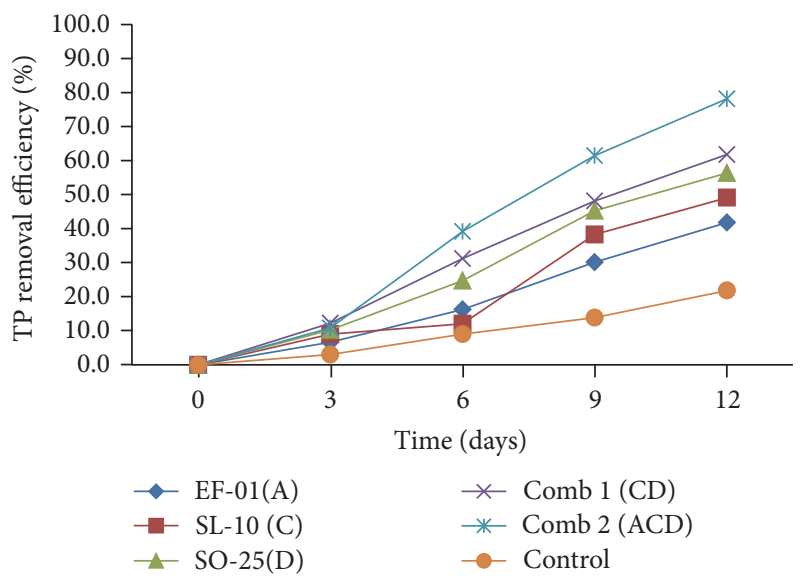

FIgURE 6: TP removal efficiency of individual and combination treatments. A: Aeromonas sp., C: Pseudomona sp., D: Bacillus sp., and Comb: combination.

Heterotrophic denitrifiers are common among the gramnegative bacteria such as Pseudomonas, Alcaligenes, Paracoccus, and Thiobacillus.

Similarly, among gram-positive bacteria (such as Bacillus), a few halophilic archaeal microorganisms (e.g., Haloferax denitrificans) are able to denitrify atmospheric nitrogen under anoxic conditions [30]. In addition, the pure cultures of bacteria capable of heterotrophic nitrification that have been documented were Alcaligenes sp. and Pseudomonas putida [31], which were closely related to the autotrophic denitrifying bacteria. In this study, Bacillus sp., Aeromonas sp., and Pseudomonas sp. were the dominant bacterial species to involve in the denitrification processes.

Another study [32] has also confirmed that Pseudomonas $\mathrm{sp}$. is the predominant heterotrophic bacteria involved in denitrification during activated sludge treatment. Also, Bhavan et al. [33] have reported that Bacillus sp. and Pseudomonas sp. have bioremediation ability of textile dye effluents which shows their waste degrading ability as indicated in this study.

3.2.4. Total Phosphorus (TP) Removal Efficiency. The removal efficiency of TP is indicated in Figure 6. The TP removal efficiency of treatments inoculated with bacterial isolates was between $42.17 \%$ and $78.31 \%$. The minimum removal was in Aeromonas sp. (EF-01) but the maximum, was recorded in combination 2 . There were statistically significant $(p<0.05)$ differences among the bacterial isolates and the control in removal of TP. Bacillus sp. had higher removal than all other individual treatments with significant difference $(p<0.05)$.

From all the treatments, the highest TP removal efficiency was in combination 2 which was $78.31 \%$ with TP value of $12 \mathrm{mg} / \mathrm{l}$. Concentrations of TP for individual isolates and their combination from the effluents did not meet national effluent emission standard limit $(5 \mathrm{mg} / \mathrm{l})$ for TP. This is because the brewery wastes contain high TP concentration $(55 \mathrm{mg} / \mathrm{l})$ before the treatment.

As in this study, Krishnaswamy et al. [10] have reported that the combination of Bacillus sp. and Pseudomonas sp. has efficiently removed the phosphate in the synthetic medium.
Another study [32] has also confirmed that Pseudomonas sp. and Aeromonas sp. were capable of phosphorus accumulation as polyphosphate from activated sludge. The results reveal that among the gram-negatives, the predominant organisms in brewery wastes such as Pseudomonas sp. accumulate the highest $\mathrm{PO}_{4}{ }^{3-}$.

Study by Brodisch and Joyner [34] has suggested that gram-positive organisms such as Streptococcus sp., Micrococcus sp., and Bacillus sp. showed reasonably high phosphateaccumulating ability. From a study conducted by Oumaima [15], pure strains of Pseudomonas aeruginosa, Moraxella lacunata, and Alcaligenes denitrificans showed remarkable efficiency in the removal of phosphate from wastewater and concluded that mixed bacterial culture strains can be used successfully for removing phosphate from wastewater.

3.2.5. TSS, TS, and TDS Removal Efficiency. The mean effluent removal efficiency of each individual treatment for TSS, TS, and TDS is presented in Figures 7(a), 7(b), and 7(c). From individual isolates, the better removal efficiency was recorded by the samples treated with Bacillus sp. with TSS (80.5\%), TS (70.18\%), and TDS (68.81\%). However, the minimum removal of the pollutants was observed in uninoculated treatment with TSS of $45.1 \%$, TS (33.64\%), and TDS (32.12\%). The removal efficiency of the selected bacterial isolates for TSS, TS, and TDS showed statistically significant $(p<0.05)$ differences among each other and with the control.

The result reveals that the treatment with three (3) mixed bacteria (comb 2) had the maximum TSS, TS, and TDS removal efficiency with $90.3 \%, 88.5 \%$, and $88.2 \%$, respectively. This shows that the synergistic effect of bacterial combination treatment brings about enhanced performance for effective biodegradation. As in this study, De Souza et al. [35] have reported that bacteria from different genera can work together in an environment and survive through the metabolites interaction because a mixed culture has more competence and has a higher tolerance to toxic metabolites.

Pseudomonas and Bacillus are the common known bacteria for brewery waste treatments. A study conducted by Anggraeni et al. [20] showed that Pseudomonas fluorescens and Aeromonas sp. isolated from soil contaminated with beer wastewater reduce total suspended solids (TSS) and total dissolved solids (TDS). Similarly, Pseudomonas aeruginosa shows good potential for use in wastewater treatment, total suspended solids (TSS), total solids (TS), and total dissolved solids (TDS) degradation [26]. This shows waste degrading ability of Pseudomonas sp. as indicated in this study.

Likewise, reduction in TSS, TS, and TDS of rubber processing effluent by using Pseudomonas sp. has been demonstrated [36]. A study by Gaikwad et al. [21] has shown that there was a maximum reduction in TSS, TDS, TS, BOD, and COD of complex wastewater by using microbial consortia of various bacterial genera, namely, Pseudomonas, Bacillus, Staphylococcus, and Streptomyces. A study conducted by Safitri et al. [37] has shown that decrease in TSS concentration is the highest in treatment containing a consortium of Bacillus pumilus, Bacillus subtilis, Bacillus coagulans, Pseudomonas putida, Bacillus licheniformis, and Nitrosomonas sp. 


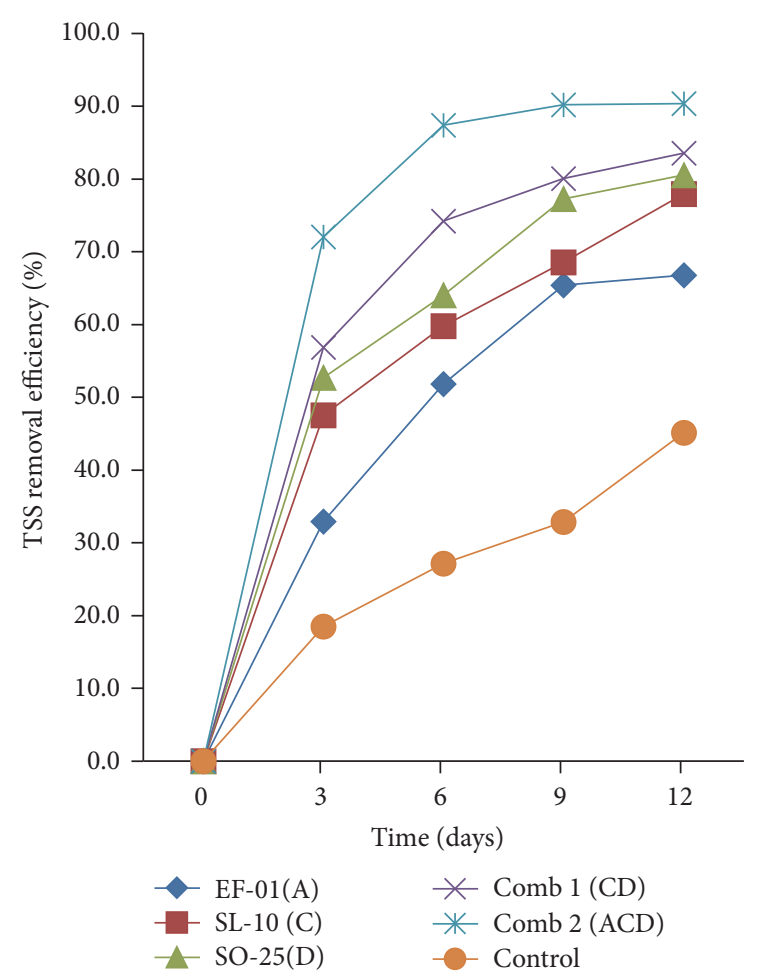

(a)

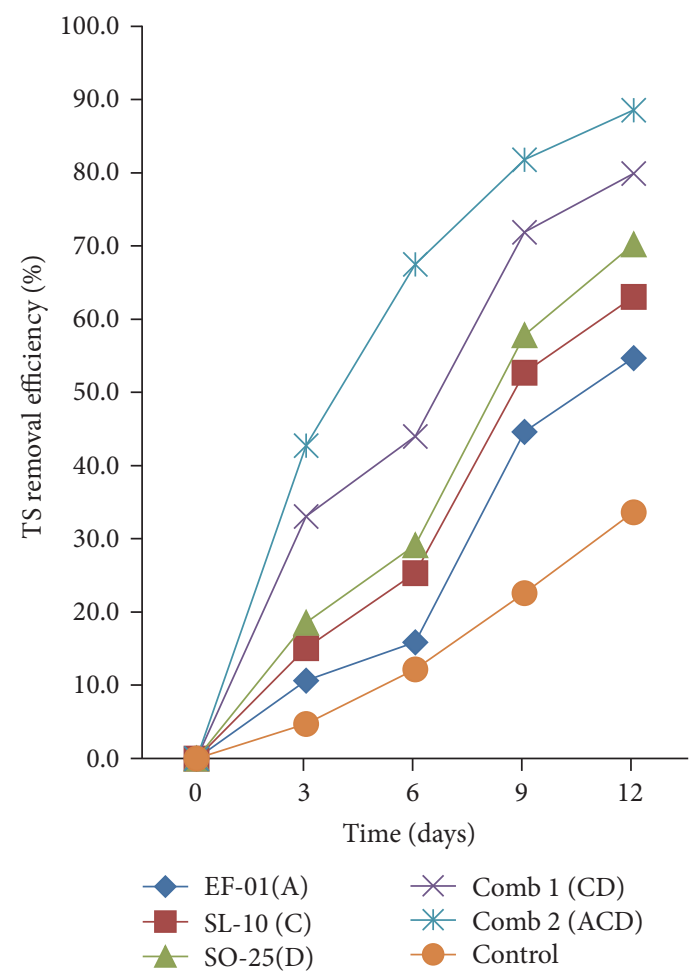

(b)

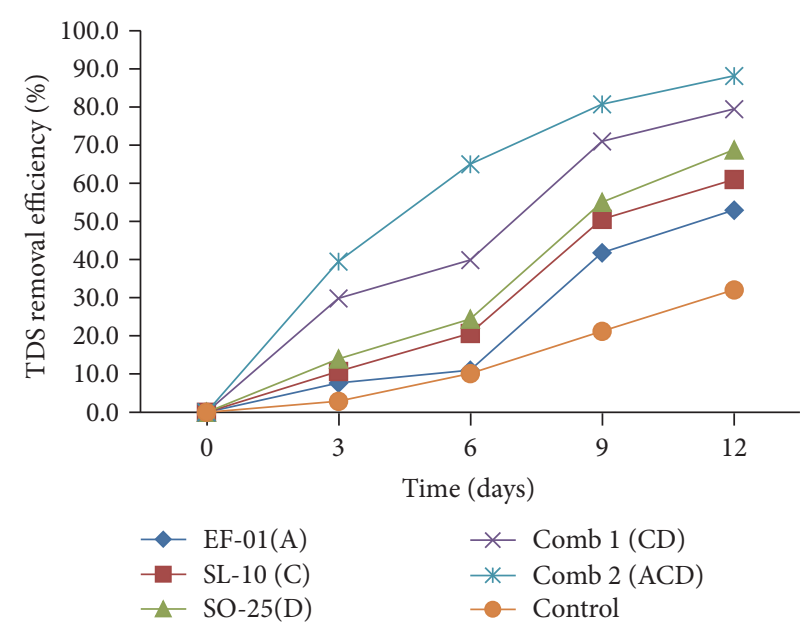

(c)

FIgure 7: TSS (a), TS (b), and TDS (c) removal efficiency (\%) of individual isolates and combination treatment. A: Aeromonas sp., C: Pseudomona sp., D: Bacillus sp., and Comb: combination.

3.3. Germination Test. Another interesting observation was that treated brewery wastes enhanced germination of beet seeds compared to the control. Mean comparison of germination percent, seedling length $(\mathrm{cm})$, and mean germination time (MGT) of beet seeds are indicated in Table 5 .

3.3.1. Germination Percent (\%). Table 5 shows that germination percent of beet root seeds ranged from $50 \%$ to $100 \%$. The results showed that germination percent of seed by wastewater before treatment was significantly lower than others $(p<0.05)$. The maximum germination percent was in combination treatment.
Seeds germination difference in untreated and treated wastes is due to presence of less toxic chemicals in the treated effluent compared to untreated effluent due to the presence of high level of toxic substances in the latter [38]. Similar to this finding, Pandey et al. [39] have shown that high concentration of distillery and brewery effluent have an inhibitory effect on seed germination and early growth of plants of maize and rice. Similarly, Ogunwenmo et al. [40] have reported that treated brewery effluent enhances seed germination in Amaranthus hybridus. Also, Yadav et al. [41] have demonstrated that sewage wastes treated with consortia of bacteria increase the percentage of germination 
TABLE 5: Germination percent (\%), mean germination time (MGT), and seedling length $(\mathrm{cm})$ after 6th day.

\begin{tabular}{lcccc}
\hline S/N & Treatment & Germination\% & MGT (days) & Seedling length (cm) \\
\hline$(1)$ & EF-01(A) & $80.00^{\mathrm{a}}$ & $4.19^{\mathrm{bcd}}$ & $5.60^{\mathrm{a}}$ \\
$(2)$ & SL-10(C) & $80.00^{\mathrm{a}}$ & $4.90^{\mathrm{abc}}$ & $5.95^{\mathrm{a}}$ \\
$(3)$ & SO-25(D) & $85.00^{\mathrm{a}}$ & $4.71^{\mathrm{abc}}$ & $6.05^{\mathrm{a}}$ \\
$(4)$ & Comb 1(CD) & $95.00^{\mathrm{a}}$ & $3.50^{\mathrm{de}}$ & $6.30^{\mathrm{a}}$ \\
$(5)$ & Comb 2 (ACD) & $100.00^{\mathrm{a}}$ & $3.10^{\mathrm{e}}$ & $6.25^{\mathrm{a}}$ \\
$(6)$ & Control & $55.00^{\mathrm{b}}$ & $5.00^{\mathrm{ab}}$ & $3.10^{\mathrm{bc}}$ \\
$(7)$ & Before treatment & $50.00^{\mathrm{b}}$ & $5.20^{\mathrm{a}}$ & $2.30^{\mathrm{c}}$ \\
$(8)$ & Tap water & $100.00^{\mathrm{a}}$ & $4.10^{\mathrm{cd}}$ & $3.80^{\mathrm{b}}$ \\
\hline
\end{tabular}

Mean values (of triplicates) followed by the same letters in each column are not significantly different $(p>0.05)$ at $95 \%$ confidence interval.

and seedlings growth of different seeds as indicated in this study.

3.3.2. Mean Germination Time (MGT). The mean germination time (MGT) of all the treatment was 3.1 to 5.2 days (Table 5). The maximum mean germination time was in untreated brewery wastes and control which were 5.2 and 5.0 days, respectively. The minimum mean germination time was in seed germinated in wastes treated with comb 2 (3.1 days). There is an increased trend of mean germination time value of the plants with increasing effluent concentrations, because of the high amount of total solids in the effluent that disturbs the osmotic relations of the seed and retarding seed germination.

A study conducted by Orhue et al. [42] showed that treated brewery effluent decreases the mean germination time of maize. Andleeb et al. [43] have found that tannery effluents caused a reduction in growth of sunflower parameters along with other parameters like chlorophyll content, protein, carbohydrate content, and so forth. Similar observations have been reported by Manu et al. [38] as indicated in this study.

3.3.3. Seedlings Length $(\mathrm{cm})$. The seedlings length of germinated beet seed after six days of incubation was minimum $(2.3 \mathrm{~cm})$ and maximum $(6.3 \mathrm{~cm})$. The minimum seedlings length was in seeds germinated in untreated wastewater, followed by control treatment. The maximum germination occurred in three combinations of isolates comb 2 (ACD), followed by comb 1 (CD). This is because untreated wastewater contains high amount of toxic substances such as high amount of total solids in the effluent; as a result germinated seed became dry [38].

In agreement with the present study, the reduction in seedling (root and shoot) lengths with the elevated amounts of total dissolved solids at higher concentrations has been demonstrated elsewhere $[44,45]$. This could also be related to the fact that some of the nutrients present in the effluents are essential but at high concentration they become hazardous. Therefore, plants irrigated with treated effluents have higher germination percentage, seedling length, and lower mean germination time (MGT) as indicated in this study.

\section{Conclusion}

Based on the results obtained with the brewery wastewater biotreatment experiments, Aeromonas sp. (EF-01), Pseudomonas sp. (S L-10), and Bacillus sp. (SO-25) were capable of reducing the pollutant parameters such as $\mathrm{pH}, \mathrm{EC}, \mathrm{BOD}$, COD, TN, TP, TSS, TS, and TDS from the brewery wastes.

In this study, the maximum pollutant removal occurred in brewery effluents inoculated with combined bacterial isolates for all parameters indicating their synergistic effect on degradation of wastes. The result also revealed that brewery wastes treated with Aeromonas sp. (EF-01), Pseudomonas sp. (SL-10), and Bacillus sp. and their mixed consortia showed enhanced germination parameters.

Generally, it can be concluded from the treatment performance of this experiment that data generated from this study can give an insight for the use of potent bacterial isolates as an alternative wastewater treatment technology.

Therefore, the development of this experimental system into a large-scale working unit offers an attractive alternative technology for waste treatment.

\section{Conflicts of Interest}

The authors declare that they have no conflicts of interest.

\section{Acknowledgments}

The authors would like to thank Heineken International Brewery S.C. and Wollega University for funding this study.

\section{References}

[1] EEPA (Ethiopian Enviromental Protection Authority), Guidline ambient Enviromental standard for Ethiopia, EPA and UNIDO, Addis ababa, 2003.

[2] C. kumar, S. A. Unnisa, and B. Rao, "Effeciency assessment of combined treatment technology," Indian Journal of fundamental and Applied life science, pp. 138-145, 2011.

[3] W. Driessen and T. dan Vereijken, Recent Developments in Biological Treatment of brewery Effluent., Zambia, The Institute and Guild of Brewing Convention, Zambia, 2003.

[4] V. Belgiorno, L. Rizzo, D. Fatta et al., "Review on endocrine disrupting-emerging compounds in urban wastewater: occurrence and removal by photocatalysis and ultrasonic irradiation for wastewater reuse," Desalination, vol. 215, no. 1-3, pp. 166-176, 2007.

[5] O. Olafadehan and D. S. Adan Aribike, "Treatment of Industrial Wastewater Effluent: Adsorption of Organic Compounds on 
Granular Activated Carbon," Journal of Chemical Engineering, vol. 19, no. 1,2, pp. 50-57, 2000.

[6] G. Bitton, Wastewater Microbiology, John Wiley \& Sons, Inc., Hoboken, NJ, USA, 3rd edition, 2005.

[7] G. Bitton, Wastewater Microbiology, Wiley-Liss, Inc, New York, NY, USA, 1999.

[8] D. Beyene and P. V. V. Prasada, "The effectiveness of waste stabilization ponds in the treatment of brewery effluent the case of Meta abo brewery waste stabilization Ponds, Sebeta, Ethiopia," Journal of research in science \& Technology, vol. 2, no. 8, pp. 11741227, 2012.

[9] J. Franklin and J. Patrick, Enviromental Enginerring Water, wastewater, soil and Groundwater Treatment and Remediaation, John Wilery and Sons, Inc, 6th edition, 2009.

[10] U. Krishnaswamy, M. Muthusamy, and L. Perumalsamy, "Studies on the efficiency of the removal of phosphate using bacterial Consortium for the Bio treatment of Phosphate wastewater," European Journal of Applied Sciences, vol. 1, no. 1, pp. 06-15, 2009.

[11] J. R. Govan and R. R. Gillies, "Further studies in the pyocine typing of Pseudomonas pyocyanea., Journal of Medical Microbiology, vol. 2, no. 1, pp. 17-25, 1969.

[12] APHA (American Puplic health Association), "Standard methods for the examination of water and wastewater," in American Public Health Association/American Water Works Association/Water Environment Federation, pp. 250-300, Washington DC, USA, 20th edition, 1998.

[13] APHA (American Public health Association), Standard methods for the Examination of Water and Wastewater, American Public Health Association, Washington, D.C, 20th edition, 1998.

[14] APHA (American Public health Association), Standard methods for the Examination of Water and Wastewater, American Public Health Association, Washington, D.C, 21st edition, 2005.

[15] N. Oumaima, "Messaoud Benounis, Leyla Benammar, Screening of Bacteria isolated from Activated Sludges for phosphate removal From Wastewater," Journal of Applied Environmental and Biological Science, vol. 5, no. 5, pp. 1-5, 2015.

[16] ISTA (International Seed Technology testing association), Seed Science Technology, r ISTA Secretariat, Switzerland, 2004.

[17] R. H. Ellis and E. H. Roberts, "Towards a rational basis for testing seed quality," in Seed Production, P. D. Hebblethwaite, Ed., Butterworths, London, 1980.

[18] R. Choudhary, P. Rawtani, and M. Vishwakarma, "Comparative study of Drinking Water Quality Parameters of three Manmade Reservoirs i.e. Kolar, Kaliasote and Kerwa Dam," Current World Environment, vol. 6, no. 1, pp. 145-149, 2011.

[19] P. Paramita, M. Shovitri, and N. D. Kuswytasari, "Biodegradation of Organic WasteMarket by Microorganism Natural Septic Tank," Journal of Science and Arts, vol. 1, no. 1, pp. 23-26, 2012.

[20] P. Anggraeni, I. Gunam, and R. Kawuri, "Potential Bacterial Consortium to Increase the Effectiveness of Beer Wastewater Treatment," Current World Environment, vol. 9, no. 2, pp. 312320, 2014.

[21] G. L. Gaikwad, S. R. Wate, D. S. Ramteke, and K. Roychoudhury, "Development of Microbial Consortia for the Effective Treatment of Complex Wastewater," Journal of Bioremediation \& Biodegradation, vol. 05, no. 04, 2014.

[22] E. S. Ralph, "Relationship between total alkalinity, conductivity, original $\mathrm{pH}$, and buffer action of natural water," Ohio Journal of Science, vol. 60, no. 5, 1960.
[23] Metcalf and Eddy, Wastewater Engineering: Treatment, Disposal and Reuse, Mc Graw Hill Book Co, New York, NY, USA, 4th edition, 2003.

[24] N. Hidayah and M. Shovitri, "Adaptation of Aerobic Bacterial Isolates Producer Hydrogen Gas in Medium Organic Waste," Journal of Science and Arts, vol. 1, pp. 16-18, 2012.

[25] W. Komarawidjaja, "Aerobic Microbial Role in Textile Wastewater Treatment," Journal of Environmental Engineering, vol. 8, no. 3, pp. 223-228, 2007.

[26] R. Bodike and S. Thatikonda, "Bio treatment of Brewery Effluent Using Pseudomonas Species," Journal of Environmental Science, Toxicology and Food Technology, vol. 8, no. 6, pp. 2319-2399, 2014.

[27] W. Mongkolthanaruk and S. Dharmsthiti, "Biodegradation of lipid-rich wastewater by a mixed bacterial consortium," International Biodeterioration and Biodegradation, vol. 50, no. 2, pp. 101-105, 2002.

[28] H. Surti, "Physico-Chemical and Microbial Analysis of Waste Water from different Industry and Cod Reduction Treatment of Industrial Waste Water by using Selective Microorganisms," International Journal of Current Microbiology and Applied Sciences, vol. 5, no. 6, pp. 707-717, 2016.

[29] R. La and G. Kuenen, Nitrogen removal from water and waste, Microbial Control of Pollution, 1992.

[30] L. Yan, Y.-L. He, H.-N. Kong, S. Tanaka, and Y. Lin, "Isolation of a new heterotrophic nitrifying Bacillus sp. strain," Journal of Environmental Biology, vol. 27, no. 2, pp. 323-326, 2006.

[31] M. Daum, W. Zimmer, H. Papen, K. Kloos, K. Nawrath, and H. Bothe, "Physiological and molecular biological characterization of ammonia oxidation of the heterotrophic nitrifier Pseudomonas putida," Current Microbiology, vol. 37, no. 4, pp. 281288, 1998.

[32] F. Bux, M. Sidat, and H. C. Kasan, "Polyphosphate accumulation by bacteria isolated from activated sludge," Centre for Water and Wastewater Research, Department of Biotechnology, vol. 25, no. 2, pp. 0378-4738, 1999.

[33] S. Bhavan, V. Srinivasan1, and J. Krishnakumar, "Bioremediation of textile dye effluent by Bacillus and Pseudomonas sp," International Journal of Science, Environment and Technology, vol. 3, no. 6, pp. 2215-2224, 2014.

[34] K. E. U. Brodisch and S. J. Joyner, "The role of micro-organisms other than Acinetobacter in biological phosphate removal in activated sludge processes," Water Science and Technology, vol. 15, no. 3-4, pp. 117-125, 1983.

[35] M. L. De Souza, D. Newcombe, S. Alvey et al., "Molecular basis of a bacterial consortium: Interspecies catabolism of atrazine," Applied and Environmental Microbiology, vol. 64, no. 1, pp. 178184, 1998.

[36] M. P. Shruthi, H. S. Raghavendra, and K. SwarnaSmitha, "Bioremediation of rubber processing industry effluent by Pseudomonas sp," International Journal of Science, Environment and Technology, vol. 2, pp. 27-30, 2012.

[37] R. Safitri, B. Priadie, M. Miranti, and A. W. Astuti, "Arum Widi Astuti, Ability of Bacterial Consortium in Bioremediation of wastewater in cisirung wastewater treatment plant," Agro life Scientific Journal, vol. 4, no. 1, pp. 2285-5718, 2015.

[38] K. J. Manu, M. V. Mohan Kumar, and V. S. Mohana, "Effect of Dairy Effluent (Treated and untreated) on Seed Germination, Seedling Growth and Biochemical Parameters of Maize (Zea mays L.)," International Journal of Environment, vol. 2, no. 2, pp. 62-69, 2012. 
[39] S. N. Pandey, B. D. Nautiyal, and C. P. Sharma, "Pollution level in distillery effluent and its phytotoxic effect on seed germination and early growth of maize and rice," Journal of Environmental Biology, vol. 29, no. 2, pp. 267-270, 2008.

[40] K. O. Ogunwenmo, O. A. Oyelana, O. Ibidunmoye, G. Anyasor, and A. A. Ogunnowo, "Effects of brewery, textile and paint effluent on seed germination of leafy vegetables-Amaranthus hybridus and Celosia argentea (Amaranthaceae)," Journal of Biological Sciences, vol. 10, no. 2, pp. 151-156, 2010.

[41] R. K. Yadav, M. C. Jain, and M. Choudhary, "Effect of media on seed germination of acid lime (Citrus aurantifolia Swingle) with or without Azotobacter," Research on Crops, vol. 13, no. 1, pp. 245-248, 2012.

[42] E. R. Orhue, A. U. Osaigbovo, and D. E. Wvioko, "Growth of maize (Zea mays L.) and changes in some chemical properties of an ultisol amended with brewery effluent," African Journal of Biotechnology, vol. 4, no. 9, pp. 973-978, 2005.

[43] S. Andleeb, N. Atiq, M. I. Ali et al., "Biological treatment of textile effluent in stirred tank bioreactor," International Journal of Agriculture and Biology, vol. 12, no. 2, pp. 256-260, 2010.

[44] A. K. Bera and B. Kanta, "Effect of tannery effluents on seed germination, Seedling growth and chlorophyll content in mung bean (Vigna radiata)," Journal of Environment and Ecology, vol. 17, pp. 955-961, 1999.

[45] G. Singh and M. Bhati, "Growth of Dalbergia sissoo in desert regions of western India using municipal effluent and the subsequent changes in soil and plant chemistry," Bioresource Technology, vol. 96, no. 9, pp. 1019-1028, 2005. 

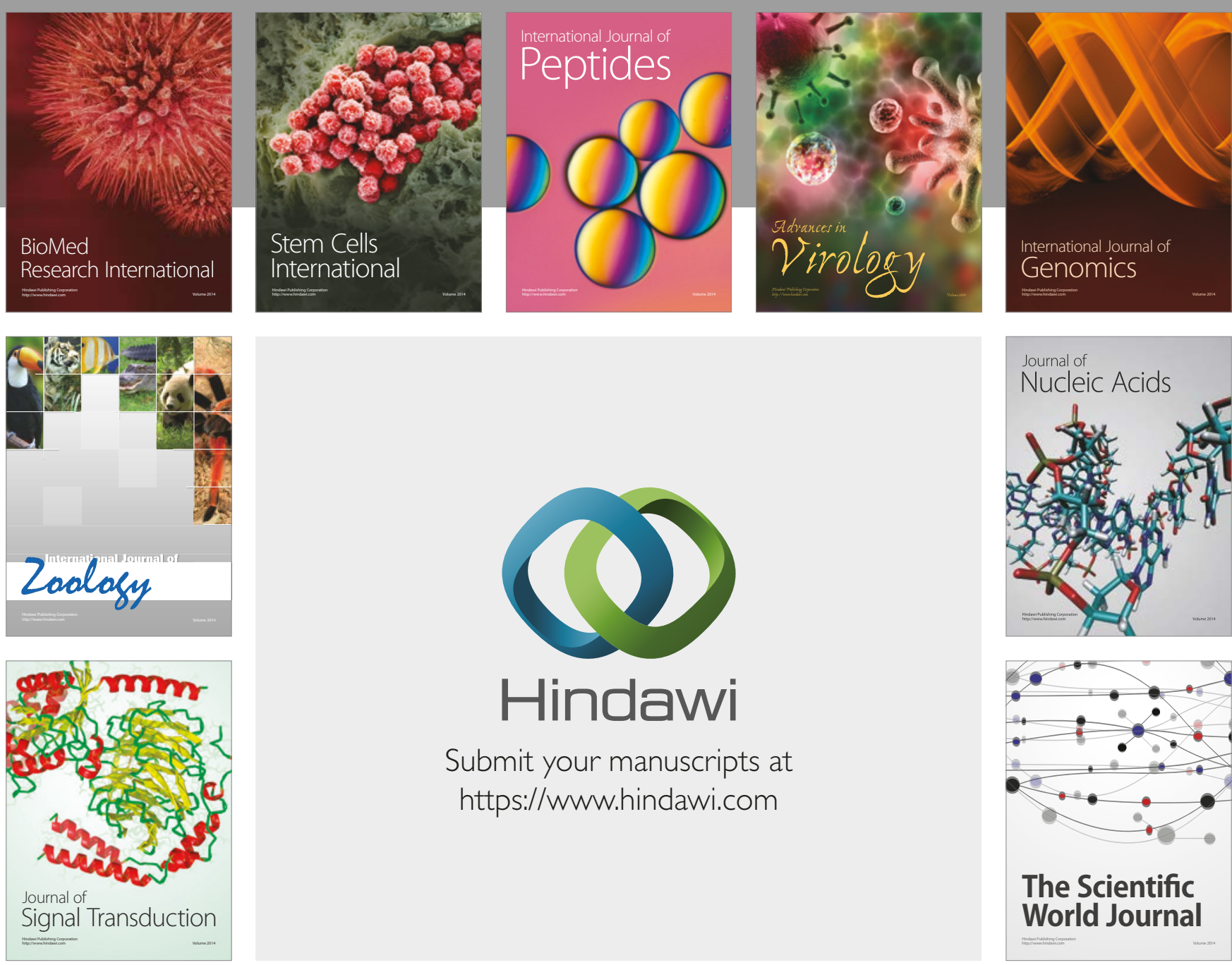

Submit your manuscripts at

https://www.hindawi.com
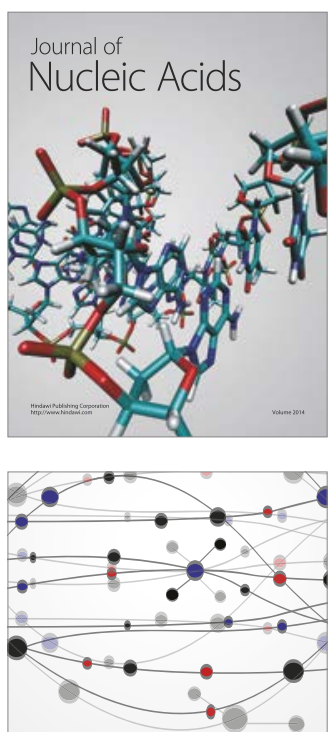

The Scientific World Journal

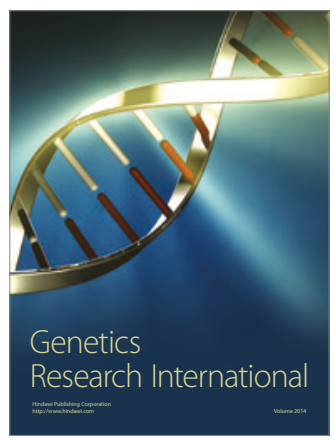

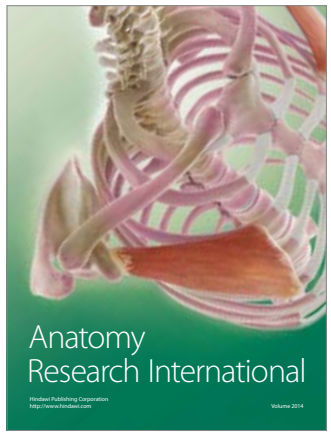

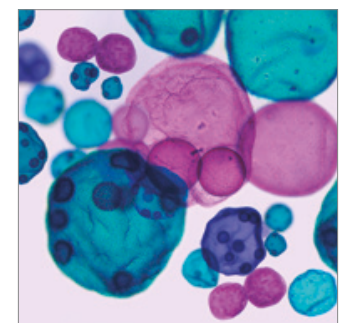

International Journal of Microbiology
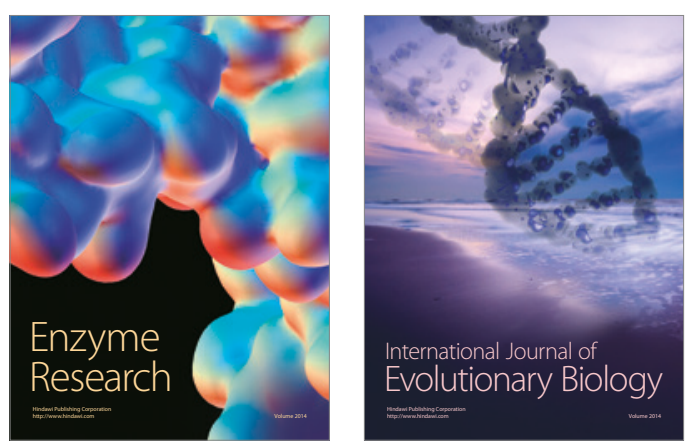
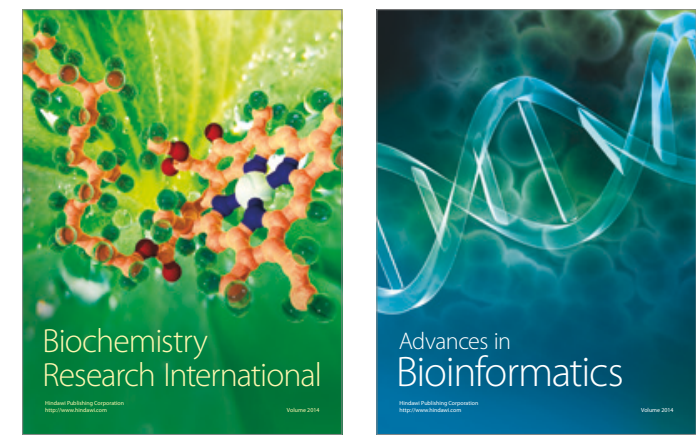

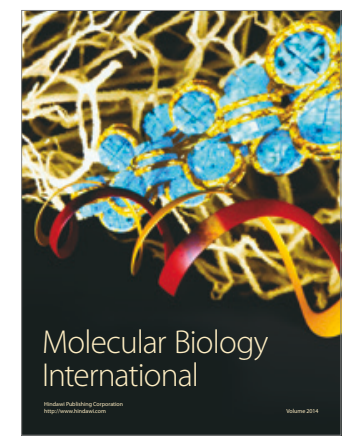

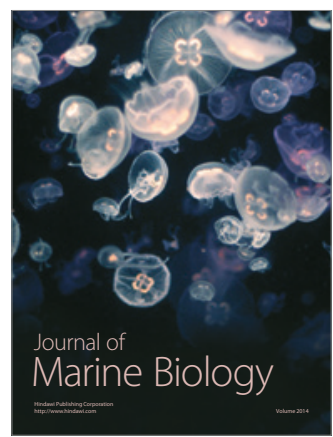

